\title{
Contextualizing Gender and Migration: Galician Immigration to Switzerland
}

\author{
Marina Richter \\ University of Bern
}

Focusing on two main aspects of the Spanish-Galician migration experience, this article attempts to analyze how migrants' actions and discourses are shaped by notions of gender. First, the discourse of returning will question notions of family and how differently men and women define their positions as members of a family. While men seem to link their social identity to immovable goods of prestige back in Galicia, women are able to redefine their social identity as they base it on social relations. The second aspect deals with the fact that cleaning is defined as women's work, but at the same time it is - under certain conditions - performed by men.

Since the 1970s, feminist migration research has evolved from the subject of the trade in women to women's migration, as Elisabeth Aufhauser (2000) states in her overview article. While some research focuses on symmetries between male and female migration - for instance women's networks as a parallel to the networks of male emigrants and kin - others highlight the specificity of female migration - for instance the emancipatory aspect of migration or the topic of sex-workers. In a first phase of any gender-sensitive science, the task of reinstating women prevails. Therefore most of the early studies in feminist migration research follow a 'compensatory' approach (Prodolliet, 1999:28). Primarily, women are written back into migration history; their part and actions in the migratory process need to be documented. This leads to studies giving a more general overview on female migration (Phizaklea, 1983; Morokvasic, 1984; Chant, 1992). In a second phase, the female standpoint is applied to analyze specific female aspects of migration. For instance, the different articles in the volume edited by Rita Simon and Caroline Brettell (1986) explore the female experience following a 'contributive' (Prodolliet, 1999:29) approach. Gender therefore becomes a

(C) 2004 by the Center for Migration Studies of New York. All rights reserved. $0197-9183 / 04 / 3801.0145$ 
category structuring the decision to migrate as well as the migratory process itself. There has been noteworthy critique from women of color and nonWestern women on the universality of the category woman. This critique led to a third phase, where the category woman was deconstructed and differentiated along different lines or axes of difference, such as race, class and ethnicity. The woman and the female experience are replaced by the plural. Not only are differences along these axes explored, the images and ideals of femininity and masculinity are questioned as well. Examples can be found in various recent works. The volume edited by Gina Buijs (1996), for instance, relates the physical crossing of a border separating two countries to the reconstruction of (gendered) identities in the new environment. Other volumes and overview articles (Gabaccia, 1992; Pessar, 1997, 1999; Brettell, 2000) further sustain the notion that migration is a highly gendered subject. From the decision to migrate, over the actual journey, on to the life in the receiving society and settling down, migration is shaped by notions of gender. At the same time, changes brought on by the decision to leave one's own well-known environment and the experiences in a different society shape the notions of femininity and masculinity (Ellis, 1996; Oso and Catarino, 1997; Mahler, 1999).

As Gina Buijs (1996) emphasizes, during the migratory process a new home and a new identity are constructed. The identities follow old idealized images brought by the migrants from their home countries, but the new ideals are never strong enough to replace the old ones completely. The home country and its image serve as a counterpoint to the real situation in the host country. To make a statement about gender relations - which always encompasses both female and male ideals and practices based on gender distinctions - and related changes, different components need to be taken into account. First, the society of origin and the prevailing gender culture serve as references for changes. In the process of reconstructing their identity, migrants make reference to their cultures of origin and build their new identities in contrast to the old ones. Second, the structural constraints in the host society, such as the structure of the labor market or public life, delimit a framework in which to negotiate new gender relations. Finally, the reasons, motives, and aims of migration need to be taken into account in order to understand how migrants are able to accept the often severe conditions in the host country. Furthermore, the features of social organization in the host country - for instance as a result of chain migration or as a consequence of local cultural associations - influence both the contact with the host society 
and the ties kept with the country of origin. From the many articles ${ }^{1}$ that deal with this issue, there is an interesting statement made by FernándezKelly (1990). Comparing two groups of Hispanic women in the United States - native- and foreign-born Mexicans in Southern California and Cuban exiles in Southern Florida - she demonstrates how migrants from comparable backgrounds and in a similar economic and social surroundings can develop different notions of familial and gendered ideals. While Mexicans migrated out of economic needs, Cubans were driven out of their country by political tensions and worked to rebuild their social and class statuses in another country. This led to a different acceptance of patriarchal models by both groups, which was based on the differing aims of their trajectories.

As research has shown, gender ideals are only apparently consistent. Rather, they prove to be contradictory and seem not to follow a straight logic (Hondagneu-Sotelo and Avila, 1997; Grasmuck and Pessar, 1991). I will be exploring this point further in this article by showing how contradictory forms of femininity and masculinity have an inherent logic that stems from the context the migrants are living and thinking in: their experiences of gender relations previous and subsequent to migration and the motives and aim of their migration trajectory. Focusing on the context as a whole brings other values into the analysis that cut across gender differences, making it possible to cross the borderline between female and male tasks.

Galician migration is in many aspects comparable to the migration of other Iberian or even Latin-American experiences. Especially compared to the Portuguese migration experience (Brettell, 1996; Barou, 1996; Klimt, 2000) many parallels emerge. Research on the broad immigration of Latin Americans to the United States and other countries leaves no doubt that features of Galician migration are found widely among other migrant groups (Guarnizo, 1997; Gmelch, 1992; Mainardi, 2001; Mahler, 1999). Therefore, the analysis will center on the piece of data that illustrates the negotiation of contradictory gender ideals and on their inherent logic. Migrants are in fact involved in tasks and actions that are contrary to their otherwise stated gender culture. This article demonstrates how a combination of fac-

\footnotetext{
${ }^{1}$ There is a wide field of scholars dealing with the question of changing gender relations among migrant communities. Clearly the ideals and praxis of migrants' gender relations in the host society cannot been disentangled from the background the migrants have left as, for example, Bhachu (1996), Fernández-Kelly (1990), Hirsch (1999), Hondagneu-Sotelo (1994) have shown.
} 
tors such as the temporary character and implicit aim of Galician migration and the immigrant status in Switzerland provide a justification for migrant's valuation of their position in the host country.

This study first discusses gender relations and working conditions in the region of origin (Galicia, Spain). In order to approach the migrants' background in Galicia, I focus on the situation as it was in the 1960s and the subsequent decades, when emigration was at its peak. In addition to the temporal restriction, there is also a spatial restriction, as the migrants are mainly from rural areas. A second part focuses on morives and aims of the migrants and highlights the gender-specific aspects. Third, the migrants' situation in Switzerland is described. Finally, I discuss the changes in gender relations that have developed and how women and men perceive these changes in different ways. The argument centers on two important gendered aspects of Spanish-Galician migration: the discourse of returning and cleaning as paid labor.

The study is based on interviews conducted between January 2000 and March 2000. Interviews were conducted with ten Galician couples in Zurich (Switzerland), interviewing them together to observe interaction among husband and wife and conducting where possible separate interviews as well. The main focus of the interviews was the migration experience, i.e., the complete process from the decision to migrate to the actual living situation. This was supplemented by questions about the perceived changes in gender relations. The couples, who were chosen by 'snowball sampling,' had all arrived in Switzerland between 1960 and 1980 and were between 35 and 60 years old. Most had family and children either in Spain or in Switzerland. Additionally, a fieldrrip to Galicia provided some data about the migrants' background. However, the majority of information is drawn from literature, as Galicia has notably developed since the time the migrants left their country: the Galicia of today can hardly be compared to that of forty or even twenty years ago. Following the development of the whole country, the region's economy enjoyed substantial growth in recent years that surpasses most growth rates in the European Union.

\section{SPANISH GALICIA - THE MIGRANTS'BACKGROUND}

A Galician saying runs: "A Galego doesn't protest, he emigrates." Since the Middle Ages, this attitude has prevailed, and large numbers of the population of the northwestern corner of Spain have sought an outlet elsewhere, creating a 'tradition of migration.' During the reconquista epoch, when the 
Catholic kings reconquered the south of Spain from the Arabs, Galician people were primarily responsible for the recolonization of the vacated areas. The discovery of a new continent in the West gave a new destination for Galician migration. Nowadays the descendants of Galicians in Latin America are still a majority among the people with Spanish roots. From the 1960s onwards, migration to Latin America decreased, and the migrants turned to destinations on the European continent. Between 1960 and 1980, 91 percent of the migratory flow concentrated on the favored countries: Switzerland (57\%), Germany (28\%) and France (6\%) (Alonso Antolín, 1984:12).

Analyzing the long tradition of migration that has persisted over centuries, it becomes clear that the motives barely changed. Galicians always migrated to earn their living elsewhere, as the economic situation in Galicia was precarious. Migration was often the only means to achieve social mobility (Buechler and Buechler, 1981:198). Many families who have attained a certain level of economic prosperity can maintain their status only by receiving remittances from emigrated family members (Buechler, 1987:228). Most of the migrants came from the rural areas of the coast or the interior part of Galicia. Agriculture, the main economic activity apart from the fishing industry, suffers from an unprofitable division of farm land: the properties are too small, and, in addition, they are divided into several plots (Bouhier, 1998). The properties are therefore difficult to mechanize and rationalize. Hence most of the farmers do not produce for the market but for their own consumption. Furthermore, at least one family member needs to work outside the farm in some form of paid labor. Such outside work was difficult to find in an economically weak region and acted as a major motive for the emigration of large numbers of the rural population.

The situation in Galicia's rural villages and hamlets of the 1960s and 1970 s is best described by the seminal work of Lisón Tolosana ( $c f .1966$, 1983 (1979)). Writing an anthropology of the entire region of Galicia, he described marriage patterns and inheritance rules for each subregion. The gendered organization he depicted is based on the powerful position of women. Recent research has differentiated the gendered social positions and questioned the matriarchal relations that Lisón Tolosana describes.

Kelley (1991) relates the case of unwed mothers in Galicia and how they are able to negotiate good reputations in their communities based on the land they own as part of an inheritance. In a later article (1999), she explores further the patterns of inheritance and how they developed over time. While daughters in this region were traditionally favored to obtain the 
millora - the greater part of the inheritance (most of the farmland and the house) - sons have equal access to it nowadays. The parents' choice depends more on the ascribed reliability of the chosen child than on gendered preferences. The same blurring of rules occurs when the marriage patterns and the locality of the newlywed's home is considered. As Roseman (1999) and Kelley (1999) argue, marriage and inheritance patterns are rather a matter of negotiation than of strict rules. Roseman (1999:118) states clearly that marriage and inheritance are not the main factors of power hierarchies. Brøgger and Gilmore (1997) follow the same line of argument: instead of focusing on marriage and its material consequences, they emphasize the emotional relatedness of family and household members, with the mother as an emotional center of the family and the household.

Looking at daily life and work in the rural areas where the migrants come from sheds further light on gendered relations and hierarchies. Everyday life in the rural areas is structured mainly by work cycles and the production constraints of agriculture. Women and men are assigned different roles and farmwork tasks, which represent social status. Two types of farms need to be distinguished. On the one hand, there are a few profitable properties where enough products can be sold to guarantee a living, consisting mainly of intensive dairy production. On the other hand, a subsistence type of farming prevails, where agricultural work and its fruits have the function of a buffer or an addition to labor market earnings (García-Ramón et al., 1993). The buffer function is depreciated in several ways. First, the production and therefore the work are not valued in economic terms on the market. Second, farm and house are linked and situated in the same building, which means that production and consumption occur at the same place. The productive part of the farm is therefore obscured by its second function as a dwelling. Third, prestige goods can only be bought with money, which in turn stems from work outside the subsistence cycle of consumption and production.

On profitable farms, women's and men's tasks are distributed along gendered patterns. As agriculture was slowly modernized, some gendered attributes and tasks changed. Nowadays, for instance, milking is done by men where before it was a woman's task. Two aspects changed in milk production: new machines were introduced, whereas before it was all manual work, and milk production has become the most important source of income in the agricultural business. More than one quarter of the national production stems from Galicia (Bouhier, 1998:45). Men are therefore seen as jefes de explotacion (head of the farm, production managers) while women 
are labeled ayudante (assistants), terms that stem from the civil law (derecho foral) that is in force (Méndez, 1987:206).

On subsistence farms, one or more male members of the family are responsible for the financial income of the family. In such a situation, work outside the house is acknowledged as 'real' work, while women's agricultural work is performed inside the closed circle of house and farm and is therefore obscured. Even if the husband in practice is not responsible for the farm, due to work outside the home and long absences, he is still the one who assumes the place of head of the farm while women call themselves 'family helpers' (García-Ramón et al., 1993:14). Comparing Galicia to the national average, it becomes clear how important women's involvement in agricultural production is: 43 percent of Galician women are economically active, 28 percent is the national average. More than half of these perform agricultural work (García-Ramón et al., 1993). ${ }^{2}$

To sum up, the work of men and women can be seen as complementary, as both produce indispensable goods that cannot replace each other. According to salary and spatial distance to the farm, male work is more highly valued than female work. The resulting relationship is therefore hierarchical. As far as basic food is concerned, men depend on their wives' work, but their relationship is construed as a one-sided dependence of the woman on her husband's income. Apparently there is a strong division of labor which applies to farming work as well as to the distinction between income-generating and nonsalaried work such as women's housework. Combining the agricultural work patterns and the issues on marriage and inheritance describes a rather equal relation between women and men. Women are in charge of the subsistence agriculture, which proves to be a pillar of stability in rural life; they generate some income, while the main incomegenerating work remains a male domain; the inheritance norms do not privilege one sex, and there are different forms of post-marital settlement. The image of equality is countered by a prevailing discourse of male superiority, which Roseman (1999:124) herself experiences as a researcher when she is silenced by other women not to interrupt men and expose her opinion on actual politics, because "women do not know" (1999:120). During my fieldtrip, I was told by a friend that in spite of her now having a driving license, neither her son nor her husband would let her drive when they sat

\footnotetext{
${ }^{2}$ There exists the possibility for women to combine farm and house work with salaried work done from home (see Bailyna and García-Ramón, 1998). Even if women earn income, their work is still linked to the house and the farm and therefore less valued than men's.
} 
with her in the car. These examples illustrate once more how ideal and praxis of gender roles differ. Women's work is appreciated, but at the same time they are reduced to their housework.

\section{AIM AND MOTTVE}

The migration from Galicia to European countries and to Switzerland officially started with the recruitment policies of the 1960s. Wealthy European countries, especially Germany, France, and Switzerland, experienced a booming economy and were searching for additional labor power to fulfill the needs of their industries. When recruitment policies began to attract the first migrants in 1961, only 158 people migrated from Galicia to Switzerland (Alonso Antolín, 1984:122). Compared to a total population of approximately 2.6 million, this seems a rather negligible number, but this small number sparked a large population movement. Three years later, the number of Galicians taking part in Spanish emigration to Switzerland rose from 3.5 percent to 35 percent, with 9,114 people leaving Galicia for the Swiss border. The number of people migrating attained its peak in 1973, when 19,688 people migrated (Alonso Antolín, 1984). From then on, emigration flow dropped drastically, falling to between 5,000 and 7,000 emigrants per year during the later 1970s and decreasing further during the 1980s and 1990s. During the early 1990s, there were still several hundred people emigrating from Galicia, whereas the official statistics for the year 1999 count only one emigrant for the whole region (INE, 1999). Nowadays the prevalent movement is not emigrating from but returning to Galicia; in the 1990 s, remigration increased from 4,532 people per year in 1990 to 8,506 in 1999 (IGE, 2001). In contrast to international migration, there still seems to be strong intranational migration, with over 26,000 people migrating from other Spanish regions to Galicia and vice versa (IGE, 2001).

In Switzerland, the Spanish population is still among the largest groups of immigrants. After Italians, Yugoslavs, and Germans, the Spanish count as the fourth-largest group, comprising 5.89 percent of the total foreign population, or almost 2 percent of the total population in 2001 in the city of Zurich (Stat. Amt d. Stadt Zürich, 2001). Rather than there being a steady number of Spaniards, their community has been reduced over the last ten or fifteen years, as the data on Galician remigration have already suggested. The Spanish and therefore also the Galician community in Switzerland mainly arrived between 1960 and 1980 and is now between 35 and 65 years old. The first immigrants arrived through governmental recruitment programs, 
and the subsequent ones followed their kin and friends who had arrived with working contracts through recruitment programs. Thus, they largely represent a body of emigrants from poorer rural areas in Galicia (for an account of early Galician immigration, see Buechler, 1987; Buechler and Buechler, 1979.

Galician migration is basically a labor migration. Until recently, many families from rural areas had no other way of surviving than by sending a member to work in another country, and migration provided further means to social mobility (Buechler and Buechler, 1981). Others migrate with a more definite material aim: they work abroad, for instance, for a year or two until their savings satisfy their ambitions to buy specific consumer items. Most, however, stay abroad for decades. The notion of being 'permanently temporary' (Grasmuck and Pessar, 1991:17) in a country is a widespread topos of migrant communities (see Gmelch, 1992; Klimt, 1989; Grasmuck and Pessar, 1991) and is a means to downsize marginality in a prosperous but alien society, as Klimt (2000) elucidates in her article on Portuguese construction of national identity in Germany. Migration is a means of social mobility, but the status attained cannot be preserved without the continuing earnings abroad. Therefore, many Galicians stay in Switzerland until they retire and return at that point to their villages of origin, where they have meanwhile built houses. As the economic possibilities in Galicia are still meager for workers over 50 years old, many Galicians wait to reach the age of retirement and return afterwards. As the data on remigration show, this process was initiated in the 1990 s, coinciding with the emigrants' retirement.

The social mobility that the migrants aim for is expressed in material items such as houses or cars, but underlying this is a double concept or career. On the one hand, a social career is pursued where founding a family is the main object. The migrants thus position themselves in the social system of kinship and village community. A family creates new ties through real and fictitious kin relations, such as godmother and godfather. On the other hand, material needs for the construction of the family's house or the restoration of the family's grave make an economic career necessary. The houses of the migrants explicitly demonstrate the economic well-being of their owners even during their absence (Buechler and Buechler, 1981). At the same time, they also symbolize a prosperous family with both social and economic connotations. A house without a family is interpreted in the Galician context as a house without a soul, while members of a family without a house are called vagabonds (Méndez, 1987:82). In her article on women's status and reputation in Galicia, Kelley (1991:568) demonstrates 
how prestige is based on the casa as house and household and how the productivity of the land is a measure for the household's wealth. House and land demonstrate symbolically a family's success. I would add to these symbols of social prestige the family grave in the communal graveyard, as the home of deceased members of the household, in which many immigrants invest a substantial part of their earnings abroad. Switzerland is one of the main destinations where Spanish-Galician migrants hoped to earn enough to fulfill their double careers.

\section{SWITZERLAND - A NEW PLACE TO FEEL AT HOME IN}

From the twenty interviewed Galicians, six had arrived with contracts and temporary permits for nine months, organized through the recruitment program. Among the five who came illegally, that is immigrating with tourist visas and then staying longer than permitted and working without work permits, there was only one man - the others were women who followed their husbands who had previously migrated to Switzerland. Joining their husbands and waiting in Switzerland for their situations to be legalized proved more effective than applying for family reunification. The latter was not included in recruitment policies, which, as in other European countries (Barou, 1995; Klimt, 2000), only focused on the (male) labor force, without acknowledging further social implications. Living with their husbands shortened the time of separation and, at the same time, wives could enter the Swiss labor market and add their earnings to the family budget.

Most of the migrants still managed to re-unify their family abroad: twelve were already married when they arrived, whereas the other eight found their partners in Switzerland. There is only one couple who met in Switzerland and afterwards sent their children to grow up with their grandparents in Galicia. In general, the children born in Switzerland stayed with their parents, and the parents tried later to bring the children they had left with their kin in Galicia to Switzerland. The importance of family unity is a common trait among migrants who migrate for their family's sake and therefore wish to keep the family united (see Gmelch, 1992 on Barbadian; Brettell, 1996 on Portuguese emigration). Family unity is not only in peril when emigrating and leaving the children behind. When the parents decide to return to their place of origin, after living in Switzerland for decades, the great majority of children stay behind, and the core family is separated a second time, an experience that applies to other migrants as well (see, for example, Gmelch, 1992). As Bolzman (1999) states, the second generation 
is decisively helped to integrate as they are socialized in school, in subsequent jobs, and with their peers, while the first generation is given little chance to integrate by the $S$ wiss society. On the one hand, assimilation is expected, but on the other hand, it is not encouraged. As far as the family and the social career of founding a family are concerned, migration seems to be a doubleedged sword.

Except for one husband who retired and is now waiting for his wife to retire also, all of the interviewed immigrants are working in one or several jobs. The migrants think of their paid work as the major objective of their stay abroad, and therefore it becomes highly valued. Most of the women start working on the black market, as they lack legal work permits. They find work as cleaners in private households. If they are lucky enough to find jobs from the beginning as assistants in cleaning or catering, they can work legally with the insurance a job in the formal sector includes. Women prevail in the service sector, especially in cleaning and catering. In addition to regular work, which ensures that the immigrants can rely on a basic set of insurance benefits, women clean private households as an informal occupation. As Hondagneu-Sotelo (1994) has shown, informal cleaning jobs often provide a possibility to enter the labor market. In contrast, however, to the Galician case, she describes how the immigrant women are in constant stress to find enough houses to clean and arrange their journeys in order to maximize their wages. The Galicians rather profit from the informality of their work: their networks provide new clients, initial training, and substitutes if a woman is ill or on a visit back home. As there is enough demand for women cleaning, the migrants can choose the houses they like and where they are well treated, leaving the others to women arriving from Latin America and other countries, who ask for lower wages and comfort themselves with more strenuous working conditions. Literature on migration usually shows how cleaning is a woman's occupation. One area that does not conform to this widely acknowledged notion is the evening cleaning jobs couples often do jointly and where wives and husbands are equally involved. I will come back to this point later to shed some more light on the topic.

Most men also work in unskilled occupations: in construction work, in factories, and in the catering sector. Among the men interviewed, there was one who had attained a better job - he was trained as a cook and now works as a chef in a Spanish restaurant. The majority of Galician women and men, however, remain in the same working conditions during all the decades of their stay. They do not pursue professionalization and development of their working conditions; on the contrary, they aim at maximizing their incomes, 
investing in additional work, such as extra hours in the evening and weekend, than in courses to improve their possibilities on the labor market.

The little spare time that is left is spent among members of the family or in one of the several cultural associations. There is hardly any mixing with the Swiss population as the language poses a major obstacle: as a matter of fact, those Galician immigrants who live in the French- and the Italianspeaking parts of Switzerland, where the spoken language is much closer to their native tongue than is German, experience less trouble integrating (Buechler and Buechler, 1979). The social life of the Galicians living in the German-speaking parts takes place therefore within the family and the Galician and Spanish-speaking populations. In Zurich alone there already exist numerous cultural clubs and immigrants' associations where people meet and where it is possible to make new acquaintances. The official club Promoción Cultura Galega acts as an administrative connection between the regional government in Galicia and the diaspora community in Zurich. The migrants also meet in various restaurants owned by Galicians and at Christian associations where the Sunday service is held in Spanish.

The question is, to what extent have gender relations been altered in a situation where labor conditions offer different opportunities for women and men compared to those in Galicia. The major change for women definitively lies in the wages they earn for their work in contrast to the unpaid work they did in Galicia. Their wages render women's work visible and comparable to men's. Their productive labor is therefore acknowledged among members of the family and the wider community as a contribution to the final aim of migration: the family's economic wealth. The women clearly achieve an economic independence they did not have before. As Galician women are often excluded from the legal labor market in the first years, they rely on networks for training and finding new clients, networks that often also include women of the households they clean.

For the men, it seems that no great changes have occurred compared to their lives in Galicia. In general, they still assume the responsibility of the breadwinner role. Out of the sample, for only two couples the wife earns the family's living, one because her husband has retired and the other because she works additional hours at her full-time job, while her husband awaits her with a cooked dinner. Migration consequently offers to Galician men the possibility to assume their responsibility as husband and father and earn enough money to provide the family's primary income. It seems that while women enjoy greater independence, men are stuck in their position. Additionally, they experience a restricted social life, as the 'plazas' and bars which 
are the places to meet others and celebrate their masculinity in Galicia (Brøgger and Gilmore, 1997) are not sufficiently replaced by the cultural associations that Galicians frequent in Switzerland. Jennifer Hirsch (1999) made the point clear in her study on Mexicans in the United States that men feel they do not 'own' the street anymore and that they are rather visitors than proprietors of the public space. In contrast to the Mexicans Hirsch writes about, who took the new situation as a rather liberating opportunity to try out new forms of masculinity, the Galicians I interviewed simply felt out of place.

\section{GENDER RELATIONS IN A CHANGED CONTEXT}

The Galician story proves comparable to other migration stories. Still, there are some pieces in my data that relate to gendered discourses and how they are actually verbalized by the migrants. Looking at how the discourse about returning develops, and questioning the arguments, highlights gendered differences that reach beyond notions of masculinity and femininity. The following section focuses on how arguments are situated in a context that draws from the migrants' (constructed) situation in their host country to explain men's involvement in cleaning work.

\section{Discourse of Returning}

The question of returning is a matter of repeated conversation among Galician migrants from the first day they arrive to the final moment of leaving Switzerland for good. It seemed to me they never tired of dreaming about the day they would return, and there were always stories recalled about others who had already left and about some friends or relatives who were making their last preparations to return. Statistical data on the immigration in Galicia of people arriving from Switzerland demonstrate that return is not only a myth but a fact. During my fieldtrip to Galicia, I actually met two families whom I knew from Zurich and who had previously returned. On the other hand, there are others who stay for good. In general, these are migrant families who during their stay in Switzerland improved their social and economic statuses; for example, a family where the wife did not need to work after a few years because her husband earned enough, allowing her to care for the children and concentrate on the housework. Again, others tried to return but then did not feel at home anymore in Galicia. One couple, who described to me their experience of returning to Galicia, presented to me a picture of all the Swiss virtues they missed in Galicia. The list seemed more 
like a stereotypical image from a traveling guide than the values they could have appreciated after living several decades in Switzerland: properness, punctuality, cleanliness, and reliability. That many Galicians return is a fact, but the issue still addresses a dimension I would call mythic and that deals not with the return itself but with the discourse about returning.

The interviews soon showed that the discourse on returning is highly gendered. During one of the interviews, when talking about the differences between Galicia and Switzerland and the family's future plans, the couple started to disagree and the situation almost ended with a quarrel. The discussion proved to give some crucial clues on the topic, and I will therefore center my analysis on it. Fernando, the husband, had been in Switzerland since his early childhood, while Ana, his wife - they had met on one of his regular vacations in Galicia - joined him after marriage. They have two sons of about twelve and nine years. Both parents work in comparably secure and well-paid jobs.

Evoking an ideal picture of Galicia, Fernando started to describe the positive aspects of returning home and living again in Galicia - notably a place he had never been living for long. He thought that there are fewer problems in Galicia, because there is always one's family if one needs help and support. In Fernando's account, Galicia is the place where he was raised. His life, his family and all the things he longs for are there. That was the point where he was briskly interrupted by Ana who countered: "What sort of life! It's here where you're living!" From her point of view he owned the house they had both paid for in Galicia, but nothing more. But there was no other reason to be longing for Galicia, as the family was with them, their children had grown up in Switzerland, and they even enjoyed having some other relatives in Zurich and in other parts of the country. But it seemed that she had touched a sore point, because Fernando insisted that he could not help feeling la morriña de la terriña, a Galician term for homesickness. Living in Switzerland equals a sacrifice: one is here to work, to earn money and save it, but not to live, as he insisted.

Apparently Ana feels more at ease in Switzerland and does not wish to return to the house they have built in Ana's and Fernando's village of origin, whereas Fernando clearly does not want to spend more time than necessary in Switzerland. Similar to other migrant groups (Brettell, 1996; Eastmond, 1996; Gmelch, 1992; Gmelch and Gmelch, 1995; Grasmuck and Pessar, 1991; Hondagneu-Sotelo, 1994; Pessar, 1997), Galician men prefer returning to their country of origin, while women have attained a status in the host 
country that they fear they will lose when remigrating. What struck me first was that both Ana and Fernando thought their family to be the main reason to stay in Switzerland or to return to Galicia. Placing this line of argument in the context of Galician symbolism and system of status provides some answers. The Galician term for homesickness gives a first glimpse of how this notion could be understood: morriña de la terriña means literally the 'longing of the little land' and describes therefore not the alienation from home but from one's land: a term that encompasses the country or region (Galicia) in a political sense, the country in a symbolical sense, and land as the agricultural soil and the lot one owns. The notion of family Fernando thinks of is deeply connected to this land for which he is longing. Family for him is a concept that promises safety and shelter and that ensures the certainty of being somebody, defined by the social ties and roots of the family's past. According to the tradition of the family, he will inherit a part of his parents' land. It seems that this notion of family relates to lines of property and therefore to roots, which originated in the family's past.

These roots are linked on the one hand to persons, i.e., the family, as a line of kinship, and on the other hand to the ground and earth, i.e., the land where a house is built and where agricultural products can be grown. The land is passed on from one generation to the next. Hence each plot symbolizes the familial line of inheritance and continuity while at the same time it also demonstrates the individuality of its proprietor. Owning land becomes a question of identity and assigns each one his or her particular place in the long family history. Apart from the temporal dimension, there is also the aspect of profession, which makes land such a powerful symbol. As long as somebody owns a piece of agricultural land, he or she is called a peasant, in a certain sense a lifelong occupation. This stands in sharp contrast to the occupational identity in Switzerland, where the occupation ends when the migrant retires.

The notion of family Ana presented encompasses the core family and to a certain extent the kin living nearby, and it is therefore based on social networks of kin. When Galician women stated to me that they had spent an important time of their lives in Switzerland, they meant the years they spent nurturing ties and relationships among members of their closest family and their wider kin. The 'kin-work' - a term coined by Micaela di Leonardo they did during all these years ensured them the support and assertion of many members of their family. Often I was told how they struggled with their teenage children to assemble the whole family on Sundays around one table. Their notion of family was built around the concept of family as a 
tight network of social relations that was present and alive. When the time approaches to decide whether to return or not, many women are confronted with a dilemma. In their role of guardians of the family spirit they are torn between accompanying their husbands and arguing for a united family. On the one hand, most men live for decades with the idea of returning one day, and it is this dream that makes their stay abroad bearable. There does not seem to be any reason not to fulfill this dream at the point of retirement from work. On the other hand, the women feel responsible for having urged the children to migrate to Switzerland. Leaving them behind means a second separation and destroys their notion of family.

Fernando's case describes a male identity that is rooted in the past. Jones-Correa (1998) shows in his analysis on Latina and Latino political participation in New York that Latinos' status among their peers depends on their status prior to migration. As they work in positions that are inconsistent to their former status, they continue to emphasize their relatedness to their country of origin and their wish to return as a strategy to cope with status inconsistency. To a certain extent, this applies as well to the Galician case, but one needs to acknowledge further how gender and notions of kinship intersect - in fact, this was urged long ago by Yanagisako and Collier (1987). Galician men do not feel their status as men endangered, rather they long for their (male) position in the social system of family and kinship. This position has fixed points of reference: the land, the house and both family's line of ancestors. Therefore men's mobility appears to be rather restricted, as they cannot transfer the points of reference to other places and are tied to their land. The alienation most Galician men feel is countered by a nostalgic picture of Galicia, a picture that idealizes the memories they guard from their childhood and teenage years and that are far away from Galicia's present reality.

This section has provided an argument regarding how men and women derive their identity from their gendered positions in the social system. On the one hand, this position is clearly gendered, but on the other hand, there are intersections with other values such as the family. The following section explores how these neatly drawn lines between the women's and the men's discourse are blurred in the context of migration.

\section{Cleaning as Paid Labor}

Virtually all of the women interviewed cleaned or had once cleaned to earn money. None of the women had worked as cleaners before in Galicia, but it 
proves to be an easy way of entering the labor market without having any qualifications. There are jobs available in the formal or in the informal market. Many work in private households without formal written contracts and therefore without any insurance, but they are accepted without possessing formal work permits. The possible inconveniences of informal work are more than balanced by the flexible organization of such work: working hours and amount of work can be adapted to the woman's and the family's needs. Some women manage from the beginning to enter the formal paid occupation and clean in hotels, restaurants or various government buildings and offices. These jobs are sought after because they can also be flexibly based on an hourly wage while at the same time offering more secure working conditions. Many women benefit from the chance to arrange their working hours according to the family's time schedule.

At first sight, cleaning seems to be a woman's job. But the women themselves state that they do not like cleaning because of the very activity. As they emphasized, they would never perform such work back in Spain. Even the (emancipatory) fact of doing paid labor as a woman does not seem very important to the women. On the contrary, one woman was relieved at not needing to work as her husband earned enough. She could thus spend her time working for the family and not for money. But the relatively good wages and the flexible working hours keep attracting women to the cleaning jobs. While they are completely aware of their low position as cleaners, they also acknowledge the difference between being a cleaner in Spain and in Switzerland. In Switzerland they experience better treatment by their employers. As migrants they are in a special position that makes it bearable. In Spain they would clean for those like themselves, while as migrants they work for people outside their community. The finality of the Galician migration helps them perform a kind of work which does not lead to high social status but which ensures an income.

In spite of all these positive arguments, cleaning is still construed as a female activity - which does not render it inferior. Men simply search for work in other sectors. Usually they have as few qualifications as their wives and are therefore restricted in their occupational choices. What the women implicate in their occupational choice, without being explicit, is the fact that they have not followed any formal training that would qualify them for the job, but as women they have acquired knowledge and skills that are needed for the job. Reasoning in this way, they follow the line of argument that cleaning work is seen as an extension of female household tasks and that therefore women are preconditioned to it (Assar, 1999; Lawson, 1998). As 
the Galician women told me, they did not need any training for the job, and the few instructions they needed were given by relatives and through networks of other Galician women. Another reason lies, of course, in the segregated labor market, a topic extensively theorized in academia (see, e.g., Hanson and Pratt, 1995; Massey, 1994 for an overview), but, nevertheless, for the women it remained out of their perception. All in all, cleaning is a task that is seen as highly gendered.

Out of the ten couples I interviewed, four cleaned offices in addition to their day working hours. Couples assume this job jointly, in spite of the contradiction to the obviously gendered character of cleaning jobs. The cleaning of offices takes place in the evening, when the staff has already left the office and the building is 'handed over' to the cleaners. Apart from the late hours, there is another interesting feature: offices are usually paid by unit and not by hour, which gives some incentive to minimize the time spent working. These points still do not clarify why men do cleaning jobs: they are not trained socially, the expansion of housework does not apply to them, and the job remains gendered. But among the couples who clean offices, all the men talked freely about these jobs and did not even think of explaining this obvious inconsistency to me. I could end the discussion at this point and conclude that my research perspective is too narrow and therefore spots problems where in reality there are none. But I believe that there is a deeper explanation and that it is worth examining.

Going back to the working conditions, there is the need to look at the late hours and the payment per unit. The first results in an empty building left over to the cleaners, who can therefore behave freely and are effectively hidden from the public. But as the offices are usually situated in large office buildings, the work is generally done by several couples together. The invisibility vis-à-vis the office staff would make it possible for men to be involved in female tasks, but at the same time the space remains public as the couples share the space with other couples. The work permit enables the person who signs the contract to bring as many people with them as they wish, as they are paid on a unit basis and not on an hourly basis. In order to finish work as quickly as possible, the couples work together instead of one going to work and the other staying at home. As one woman noted with a sad smile, they work so many hours a day, at least working together in the evening allows them to see each other. The family as a source of cheap labor power and easily accessible support is known from literature on family and ethnic business. But as Assar (1999) makes clear in a study on Gujarati motel 
owners in the United States, if the business builds on the family as a source of labor power, labor is usually distributed along gender differences. While men were mostly in charge of 'talking' to new customers and the administrative tasks, women did the cleaning, tidying up of the rooms and cooking, because these tasks seem more appropriate for women.

Leading the question back into the Galician context might provide some useful reasons to overcome the contradiction. Firstly, recalling the aim of Galician migration, which consists of earning as much money as possible in order to allow the family's social mobility, helps to understand that there might be reasons that are stronger than a distinction based on gender. It is the same line of argument Galician women use when talking about their own cleaning work: it might not be work they do with pleasure and it contrasts with their ideal of caring for their children and family, but for the family's sake they assume the burden. Second, the temporary nature of migration Galicians always insist on creates a situation of a social bracket in Switzerland. Repeatedly they told me: "I live here, but my heart is in Galicia." They stated that the social reality happened in Galicia, and they were only physically living here. Such a bracket blurs social rules and norms and creates a space where the dominant rule is to maximize income and earnings in order to return soon to Galicia. Finally, migrants are well aware of their social status in the host society. Apart from the constraints the status as migrants imposes upon them, they are able to use the label 'migrants' to justify their life and working conditions vis-à-vis their self-esteem. As has been analyzed for other immigrant groups (see, e.g., Jones-Correa, 1998) the strategy of accepting work disregarding its social connotation or value and justifying this decision by relating it to the condition as a migrant proves to be a viable strategy to prevent status inconsistency.

There still remains the final question if men can clean in the evening, why is there no example of a man cleaning during the day as his major job? The late hours of office cleaning not only seclude the workers from the office staff, they also result in separating it from the working day and making it an additional but only a part-time job. The Galician men I interviewed always mentioned first the work they did during daytime, referring to their tasks in construction or any other occupation as their job. Only after that the office cleaning job was mentioned and described to me. In this way they made it clear that their 'real' or main job was always the work they performed during the day. The gendered aspects could therefore be neglected, as they blurred in the migrants' context. 


\section{CONCLUSION}

Focusing on two aspects of the Galician migration experience, I have analyzed how notions of gender shape migrants' actions and discourses. The discourse of returning lead me to question notions of family and how men and women define their position as members of a family differently. Galician men seem to link their social identity to immovable goods like their house and land back in Galicia, whereas women's identity is linked to the family they have built in Switzerland and is therefore based on social relations. This way of defining one's identity as relational proves as a resource for Galician women as they are able to feel 'at home' in Switzerland, while their husbands still long for their land after decades of living and working abroad.

Analyzing the cleaning labor couples perform jointly in the evenings showed the importance of acknowledging the context migration provides for gendered tasks such as cleaning work. The main aspects I found important in explaining why men could involve themselves in cleaning without feeling less a man were the clear wish to return, which made the stay 'eternally temporary,' and the overall goal to earn as much as possible to build a comfortable future for the family back in Galicia. This resulted in a social bracket, a space where it was possible to transgress gendered borders in order to earn and save as much as possible.

The first line of argument exemplifies how migrants' actions and abilities are gendered and how these notions of gender are linked to a cultural concept of kinship and family that apparently differs for men and women. But this difference only becomes visible in the separation from home. The second line of argument stresses the need to analyze gender and migration in the context of the specific community. The notions of temporality and the material goal of earning money abroad provide a framework to understand the blurred boundaries of gendered labor.

Two major claims emerge from this line of argument. First, migrants do not define themselves in sharp categories. While acknowledging that there is a significant difference between the two sexes, they rather build their ideals and discourses on social roles that are partly gendered but also partly shaped by other categories. This case mainly elaborates on the intersection of gender and family roles and ideals. It is men's social and familial roles as fathers that pull them back to Galicia, the only place which provides the social context and prerequisites for a male role linked to the family and its line of descent. And it is, on the other hand, the position Galician women 
have achieved as mothers in a sense of social relations that helps them to feel 'at home' in Switzerland.

Second, there is a need for more research on men's strategies and ideals as gendered. My emphasis on Galician men's discourse of returning and their transgression of gendered boundaries in cleaning work demonstrates how gender impinges on men's notions the same as on women's. The roles, ideals and life courses men define for themselves and aim at are negotiated in a context that derives from the migrants' situation in the host country and the notions and ideals attributed to their society of origin. Both are structured by gender and it becomes therefore impossible to explain men's decisions and actions without acknowledging their gendered aspects.

\section{REFERENCES}

Alonso Antolín, M. C.

1984 La Emigración Gallega Asistida a la República Federal de Alemania, Francia y Suiza. Madrid: Instituto Español de Emigración.

Assar, N. N.

1999 "Immigration Policy, Cultural Norms, and Gender Relations among Indian-American Motel Owners." In Gender and Immigration. Ed. G. Kelson and D. Delaet. London: Macmillan Press. Pp. 82-102.

Aufhauser, E.

2000 "Migration und Geschlecht: Zur Konstruktion und Rekonstruktion von Weiblichkeit und Männlichkeit in der internationalen Migration." In Internationale Migration: Die Globale Herausforderung des 21. Jahrhunderts? Ed. K. Husa et al. Wien: Brandes \& Apsel/Südwind.

Barou, J.

1996 "Portugais d'Auvergne. D'une Identité Villageoise à l'Autre," Revue d'Auvergne, $110(2): 147-159$.

Baylina, M. and M. D. García-Ramón

1998 "Homeworking in Rural Spain: A Gender Approach," European Urban and Regional Studies, 5(1):55-64.

Bhachu, P. K.

1996 "Identities Constructed and Reconstructed: Representations of Asian Women in Britain." In Migrant Women. Crossing Boundaries and Changing Identities. Ed. G. Buijs. Oxford, WA: Berg. Pp. 83-117.

Bolzman, C.

1999 "Le Parcours de deux Générations d'Immigrés: un Chemin d'Intégration?" In Populations Immigrées: Quelle Insertion?' Quel Travail Social? Ed. C. Bolzman and J.-P. Tabin. Genève, Lausanne: Editions IES; Cahiers de l'EESP. Pp. 41-56.

Bouhier, A.

1998 "Lourdeurs du Passé: La Situation Actuelle de l'Agriculture Galicienne (1956-1966)," Annales de Géographie, 599:33-58. 
Brettell, C. B.

2000 "Theorizing Migration in Anthropology: The Social Construction of Networks, Identities, Communities, and Globalspaces." In Migration Theory. Talking across Disciplines. Ed. C. B. Brettell and J. F. Hollifield. London, New York: Routledge. Pp. 97-135.

1996 "Women are Migrants Too. A Portuguese Perspective." In Urban Life. Readings in Urban Anthropology. Ed. G. Gmelch and W. P. Zenner. Prospect Heights: Waveland. Pp. 245-258.

Brettell, C. B. and R. J. Simon

1986 International Migration: The Female Experience. Totowa, NJ: Rowman \& Allanheld Publishers.

Brøgger, J. and D. D. Gilmore

1997 "The Matrifocal Family in Iberia: Spain and Portugal Compared," Ethnology, 36(1): 13-30.

Buechler, H.-C.

1987 "Spanish Galician Migration to Switzerland: Demographic Processes and Family Dynamics." In Migrants in Europe: The Role of Family, Labor, and Politics. Ed. H.-C. Buechler and J.-M. Buechler. New York, Westport, CT, London: Greenwood Press. Pp. 221-264.

Buechler, H.-C. and J.-M. Buechler

1981 Carmen: The Autobiography of a Spanish Galician Woman. Cambridge, MA: Schenkmann Publishing Company.

1979 "Los Suizos: Galician Migration to Switzerland." In Migration and Ethnicity. Ed. H. Safa and B. Dutoit. The Hague: Manton. Pp. 17-29.

Buijs, G.

1996 Migrant Women. Crossing Boundaries and Changing Identities. Oxford, WA: Berg.

Chant, $\mathrm{S}$.

1992 Gender and Migration in Developing Countries. London, New York: Belhaven Press.

Eastmond, $M$.

1996 "Reconstructing Life: Chilean Refugee Women and the Dilemmas of Exile." In Migrant Women. Crossing Boundaries and Changing Identities. Ed. G. Buijs. Oxford, WA: Berg. Pp. 35-53.

Ellis, M. et al.

1996 "The Circular Migration of Puerto Rican Women: Towards a Gendered Explanation," International Migration, 34(1):31-63.

Fernández Kelly, P.

1990 "Delicate Transactions: Gender, Home, and Employment among Hispanic Women." In Uncertain Terms. Ed. F. Ginsburg and A. Lowenhaupt Tsing. Boston: Beacon Press. Pp. 183-195.

Gabaccia, D.

1992 Seeking Common Ground: Multidisciplinary Studies of Immigrant Women in the United States, Westport, CT: Greenwood Press.

Garcia-Ramón, M. D. et al.

1993 "Farm Women, Gender Relations and Household Strategies on the Coast of Galicia," Geoforum, 24(1):5-17. 
Gmelch, G.

1992 Double Passage. The Lives of Caribbean Migrants Abroad and Back Home. Ann Arbor: University of Michigan Press.

Gmelch, G. and S. Gmelch

1995 "Gender and Migration. The Readjustment of Women Migrants in Barbados, Ireland, and Newfoundland," Human Organization, 54:470-473.

Grasmuck, S. and P. R. Pessar

1991 Two Islands: Dominican International Migration. Berkeley: University of California Press.

Guarnizo, L. E.

1997 "The Emergence of a Transnational Social Formation and the Mirage of Return Migration among Dominican Transmigrants," Identities, 4(2):281-322.

Hanson, S. and G. Pratt

1995 Gender, Work, and Space. London, New York: Routledge.

Hirsch, J. S.

1999 "En el Norte la Mujer Manda. Gender, Generation, and Geography in a Mexican Transnational Community," American Behavioral Scientist, 42(9):1332-1349.

Hondagneu-Sotelo, P.

1999 "Gender and Contemporary U.S. Immigration," American Behavioral Scientist, 42(4): $565-576$.

1994 Gendered Transitions: Mexican Experiences of Immigration. Berkeley: University of California Press.

Hondagneu-Sotelo, P. and E. Avila

1997 "'I'm Here, but I'm There': The Meanings of Latina Transnational Motherhood," Gender and Society, 11(5):548-571.

IGE (Instituto Galego de Estatistica)

2001 Galicia en Cifras. Yearbook of the Galician Statistical Office.

INE (Instituto Nacional de Estadistica)

1999 Inebase. Database maintained by the Spanish National Statistical Office. Madrid, Spain.

Jones-Correa, $\mathrm{M}$.

1998 "Different Paths: Gender, Immigration and Political Participation," International Migration Review, 32(2):326-349.

Kelley, H.

1999 “'If I Really Were a Wirch': Narratives of Female Power in a Coastal Galician Community," Anthropologica, 41:133-141.

1991 "Unwed Mothers and Household Reputation in a Spanish Galician Community," American Ethnologist, 18(3):565-580.

Klimt, A.

2000 "Enacting National Selves: Authenticity, Adventure, and Disaffection in the Portuguese Diaspora," Identities, 6(4):513-550.

1989 “'Returning Home': Portuguese Migration Notions of Temporariness, Permanence, and Commitment," New German Critique, 46:47-70. 
Lawson, V.

1998 "Hierarchical Households and Gendered Migration in Latin America: Feminist Extensions to Migration Research," Progress in Human Geography, 22(1):39-53.

Lisón Tolosana, C.

1983 Antropologia cultural de Galicia. Madrid: Akal Universitaria. (1979)

1966 Belmonte de los Caballeros: A Sociological Study of a Spanish Town. Oxford: Oxford University Press.

Mahler, S. J.

1999 "Engendering Transnational Migration. A Case Study of Salvadorans," American Behavioral Scientist, 42(4):690-719.

Mainardi, G.

2001 "Femmes Brésiliennes Immigrées en Suisse. Un Éssai de Comprehension du Phénomène." In Savoirs et Enjeux de l'Interculturel. Ed. C. Sabatier et al. Paris: L'Harmattan. Pp. 11-26.

Massey, D.

1994 Space, Place, and Gender. Minnesota: Polity Press.

Méndez, L.

1987 'Cousas de Mulleres': Campesinas, Poder y Vida Cotidiana (Lugo, 1940-1980). Anthropos.

Morokvasic, $\mathrm{M}$.

1984 "Birds of Passage Are Also Women..." International Migration Review, 18(4):886-907.

Oso, L. and C. Catarino

1997 "Les Effets de la Migration sur le Statut des Fernmes: le Cas des Cominicaines et des Marocaines à Madrid et des Cap Verdiennes à Lisbonne," Migrations Société, 9(52): 115-130.

Pessar, P. R.

1999 "Engendering Migration Studies. The Case of New Immigrants in the United States," American Behavioral Scientist, 42(4):577-600.

1997 Caribbean Circuits: New Directions in the Study of Caribbean Migration. New York: Center for Migration Studies.

Phizacklea, A.

1983 One Way Ticket? Migration and Female Labour. London: Routledge.

Prodolliet, $\mathrm{S}$.

1999 "Spezifisch Weiblich: Geschlecht und Migration. Ein Rückblick auf die Migrationsforschung," Zeitschrift für Frauenforschung, 17(1\&2):26-42.

Roseman, S.

1999 "¿Quen Manda? (Who's in Charge?): Household Authority Politics in Rural Galicia," Anthropologica, 41:117-132.

Stat. Amt d. Stadt Zürich

2001 Bevölkerung. Demographic database maintained by the Statistical Office of the City of Zurich, Switzerland.

Yanagisako, S. J. and J. F. Collier

1987 "Toward a Unified Analysis of Gender and Kinship." In Gender and Kinship. Essays Toward a Unified Analysis. Ed. J. F. Collier and S. J. Yanagisako. Stanford, CA: University Press. Pp. 14-50. 